\title{
Evaluasi Penerapan SIMDA Keuangan pada Dinas Kepemudaan Olahraga dan Pariwisata Kota Magelang
}

\author{
Siti Muthoharoh ${ }^{1}$, Agustina Prativi Nugraheni $^{2}$ \\ ${ }^{1}$ Akuntansi, Universitas Tidar \\ e-mail: smuthoharoh31@gmail.com \\ ${ }^{2}$ Akuntansi, Universitas Tidar \\ e-mail: devi.agustina@untidar.ac.id
}

\begin{abstract}
This study aims to evaluate the application of the regional financial management information system (SIMDA) at the Dinas Kepemudaan Olahraga dan Pariwisata Kota Magelang (DISPORAPAR). Furthermore, this study also aims to determine strategic steps to be taken by local governments in implementing SIMDA Finance by taking a case study at the Dinas Kepemudaan Olahraga dan Pariwisata Kota Magelang. This research data collection activities using the method of observation and interviews and using supporting instruments in the form of e-interview forms. The results of this study can be seen that the overall quality of the system produced by SIMDA for the Youth, Dinas Kepemudaan Olahraga dan Pariwisata Kota Magelang is good. The results obtained from the evaluation of the implementation of the SIMDA Finance at the Magelang City Youth Sports and Tourism Office are in the form of a percentage value using Arikunto calculations with a result of $68.52 \%$. Five usability criteria are used as standards for analyzing the extent to which the SIMDA application has been applied, so that it can be seen what weaknesses are and thus can be made improvements to the system.
\end{abstract}

Keywords: Evaluation, Regional Management Information System (SIMDA), Finance

\begin{abstract}
Abstrak
Penelitian ini bertujuan untuk mengevaluasi penerapan Sistem Informasi Manajemen Daerah (SIMDA) Keuangan pada Dinas Kepemudaan Olahraga dan Pariwisata Kota Magelang (DISPORAPAR). Selanjutnya, penelitian ini juga bertujuan untuk mengetahui langkah yang strategis untuk dilakukan oleh pemerintah daerah dalam penerapan SIMDA Keuangan dengan mengambil studi kasus pada Dinas Kepemudaan Olahraga Dan Pariwisata Kota Magelang. Kegiatan pengumpulan data pada penelitian kali ini menggunakan metode
\end{abstract}


observasi dan wawancara dan menggunakan instrumen pendukung dalam bentuk $e$-formulir wawancara. Hasil penelitian ini dapat diketahui bahwa kualitas sistem yang dihasilkan SIMDA Keuangan Dinas Kepemudaan Olahraga dan Pariwisata Kota Magelang secara keseluruhan sudah baik. Hasil yang diperoleh dari evaluasi penerapan SIMDA Keuangan pada Dinas Kepemudaan Olahraga dan Pariwisata Kota Magelang adalah dalam bentuk nilai persentase menggunakan perhitungan arikunto dengan hasil sebesar 68,52\%. Lima kriteria kegunaan digunakan sebagai standar untuk menganalisis sejauh mana aplikasi SIMDA telah diterapkan, sehingga dapat diketahui apa kelemahan sistem dan dengan demikian dapat dilakukan perbaikan pada sistem.

Kata kunci : Evaluasi, Sistem Informasi Manajemen Daerah (SIMDA), Keuangan

\section{PENDAHULUAN}

Sistem informasi dan program aplikasi Komputer saat ini menjadi sangat penting untuk era saat ini dan memiliki peran sangat luas tak terkecuali bagi berbagai organisasi di lingkup pemerintah daerah, Karena dalam hal ini sangat membantu proses kegiatan yang terjadi di pemerintahan daerah, sehingga proses ini meningkatkan efisiensi, efektivitas dan komunikasi. Undang-Undang nomor 17 tahun 2003 menerangkan tentang Keuangan Negara dan juga menjelaskan ruang lingkup bab Keuangan Negara bahwa semua hak dan kewajiban negara yang dapat dinilai dengan uang milik negara. Salah satu penyebab kelemahan undang-undang pengelolaan keuangan Negara yaitu terjadinya suatu bentuk penyimpangan pengelolaan keuangan negara. Sehingga perlu kiranya untuk berpikir kembali mengenai konsep Keuangan Negara yang tepat dan sesuai. Salah satu bentuk upaya yang dilakukan dengan mewujudkan suatu sistem pengelolaan keuangan yang baik supaya berkesinambungan dan sesuai aturan yang menjadi pokok dalam undangundang dan asas yang berlaku universal. Dalam hal ini, pemerintah Negara perlu penyelenggaraan suatu Undang-Undang yang nantinya menjadi pertimbangan dalam Undang-Undang nomor 17 tahun 2003, yaitu:

a. Penyelenggaraan oleh Negara dalam mewujudkan tujuan bernegara yang menimbulkan hak dan kewajiban Negara. 
b. Pengelolaan hak dan kewajiban Negara telah diatur dalam Bab VIII UUD 1945.

c. Pasal 23C Bab VIII UUD 1945 mengenai keuangan Negara diatur dengan undang-undang.

d. Perlunya untuk dibentuk undang-undang tentang keuangan Negara.

Pemerintah Indonesia pertama kali memiliki standar yang telah ditetapkan dalam Peraturan Pemerintah Nomor 24 Tahun 2005, yang kemudian diubah menjadi Peraturan Pemerintah Nomor 71 Tahun 2010, yang ke-dua Peraturan Menteri Keuangan (PMK) Nomor 283 Tahun 2011 menjelaskan mengenai Pedoman Umum Sistem Akuntansi Pemerintahan (PUSAP). Yang terakhir Peraturan Menteri Dalam Negeri (permendagri) Nomor 64 Tahun 2013 menjelaskan tentang Penerapan Standar dalam Akuntansi Pemerintah yang Berbasis Akrual pada setiap Pemerintah Daerah.

Dalam organisasi pemerintah berkewajiban untuk menyampaikan laporan keuangannya kepada publik. Supaya dapat melakukan pengolahan data keuangan secara efektif, efisien dan akurat. Maka, dibutuhkan suatu Sistem Informasi yang terintegrasi dan yang dapat diandalkan, Sehingga sistem informasi yang dihasilkan secara menyeluruh dapat memberikan informasi yang andal, akurat dan relevan untuk pengambilan suatu keputusan.

Pemerintahan Kota Magelang telah mengembangkan Sistem Informasi Manajemen Daerah (SIMDA) berbasis akrual yang digunakan untuk pengelolaan keuangan daerah secara terintegrasi yang nantinya akan digunakan untuk pengambilan suatu keputusan dalam berbagai hal di sektor pemerintahan (bpkad.magelangkota.go.id). SIMDA ini adalah alat yang digunakan untuk mengontrol dari berbagai aktifitas yang sedang terjadi di masing-masing Satuan Kerja Perangkat Daerah (SKPD) Kota Magelang. Kemudian SIMDA Keuangan ini digunakan sebagai bahan untuk membuat laporan keuangan SKPD di Kota Magelang. Mengenai pengelolaan keuangan daerah, Pemerintahan di Kota 
Magelang telah melakukan kerja sama dengan BPKP dalam penggunaan Sistem Informasi Manajemen Daerah Keuangan (bpsdmd.jatengprov.go.id). Dalam Penerapan SIMDA keuangan di Kota Magelang digunakan dalam perencanaan Keuangan dan pelaporan kegiatan pengelolaan keuangan yang ada di Organisasi Perangkat Daerah (OPD).

Pelaksanaan dan penerapan SIMDA di Dinas Kepemudaan Olahraga dan Pariwisata Kota Magelang ditemukan ada beberapa kendala seperti kualitas SDM dan kuantitas SDM yang diketahui masih kurang dalam pengelolaan dan penerapan SIMDA tersebut. Namun demikian, kendala seperti prosedur dan panduan yang terintegrasi juga masih perlu diperhatikan dalam pengaplikasian SIMDA Keuangan.

Berdasar latar belakang yang telah disebutkan sebelumnya kemudian peneliti tertarik melakukan penelitian ini dengan judul Evaluasi Penerapan SIMDA Keuangan pada Dinas Kepemudaan Olahraga dan Pariwisata di Kota Magelang. Tujuan dalam penelitian ini adalah untuk mengevaluasi Penerapan Sistem Informasi Manajemen Daerah (SIMDA) Keuangan yang ada di Dinas Kepemudaan Olahraga dan Pariwisata atau (DISPORAPAR) Kota Magelang.

1. Sistem Informasi Manajemen Daerah (SIMDA)

Gaol, 2008:15 merangkum Sistem Informasi Manajemen adalah sebuah kesatuan, sistem mesin pengguna yang sudah terintegrasi dalam memberikan informasi yang mendukung operasi, manajemen dan fungsi pembuatan keputusan dalam suatu organisasi. sistem yang dimaksud yaitu yang menggunakan hardware dan software komputer, prosedur manual, model yang digunakan untuk menganalisis, merencanakan, mengendalikan, dan membuat keputusan serta sebuah basis data. Menurut Mcleod (2004:11) mendiskripsikan bahwa Sistem Informasi Manajemen adalah sistem program aplikasi berbasis komputer yang nantinya digunakan untuk menyediakan informasi bagi pengguna yang memiliki kebutuhan yang sama. Lebih lanjut menurut deskripsi 
dari Kumorotomo (2004:9) menjelaskan bahwa unsur-unsur yang mewakili Sistem Informasi adalah masukan (input), pengolahan (processing), dan keluaran (output). (Machmud dan rizan: 2013) Secara umum, Sistem Informasi Manajemen adalah merupakan suatu sistem yang bisa membantu manajemen dalam pengumpulan, pengolahan, analisis dan evaluasi data dan menyajikannya kedalam informasi yang bernilai sampai pada pengambilan suatu keputusan dimana informasi tersebut berguna untuk mendukung fungsi dari operasi manajemen daerah.

SIMDA atau Sistem Informasi Manajemen Daerah yaitu, program aplikasi yang digunakan sebagai aplikasi pembantu dalam proses administrasi dan pengelolaan keuangan pada pemerintah daerah, mulai dari tingkat provinsi sampai di tingkat kelurahan. SIMDA Keuangan terdiri 26 aplikasi sistem terpisah yang dapat disalurkan di setiap Satuan Kerja Perangkat Daerah, dengan sistem database yang sudah terintegrasi, sehingga hasilnya dapat digunakan oleh pimpinan daerah dalam proses pengambilan suatu keputusan. Di sisi lainnya juga dapat melakukan pemantauan terhadap kinerja pengelolaan keuangannya pada pemerintah daerah. SIMDA menjadi upaya untuk memenuhi kebutuhan informasi keuangan secara cepat, tepat, lengkap, akurat dan komprehensif. SIMDA juga menjadi alat penunjang proses administrasi pemerintahan Daerah dan pelayanan masyarakat. Menurut hasil penelitian Djaja dalam penelitian yang dilakukan oleh (Budiman, Fuad dan Arza, Fefri Indra : 2013), Aplikasi SIMDA merupakan suatu program aplikasi yang bertujuan untuk mempermudah pengelolaan keuangan di lingkungan Satuan Kerja Perangkat Daerah (SKPD).

2. Keluaran yang dihasilkan SIMDA Keuangan

a. Bidang Penganggaran, yaitu:

1) Rencana kerja anggaran (RKA)

2) Dokumen pelaksanaan anggaran (DPA) 
3) Surat penyediaan dana (SPD)

b. Bidang Penatausahaan, yaitu:

1) Surat permintaan pembayaran (SPP)

2) Surat perintah membayar (SPM)

3) Surat perintah pencairan dana (SP2D)

4) Surat tanda setoran (STS)

5) Register

6) Surat pengendalian lainnya

c. Bidang Akuntansi dan Pelaporan, yaitu:

1) Jurnal

2) Buku besar

3) Buku pembantu

4) Laporan Realisasi Anggaran

5) Laporan Arus Kas

6) Neraca

d. Program Aplikasi SIMDA keuangan juga didukung dengan beberapa hal, antara lain:

1) Buku manual sistem dan prosedur penganggaran

2) Buku manual sistem dan prosedur penatausahaan

3) Buku manual sistem, prosedur akuntansi dan pelaporan

4) Buku pedoman untuk pengoperasian aplikasi SIMDA Keuangan

3. Fungsi utama dari implementasi SIMDA Keuangan yaitu:
a. Melaksanakan pengelolaan keuangan daerah (penganggaran, pelaksanaan, pertanggungjawaban)
b. Menyusun laporan keuangan lebih efisien dan lebih akurat
c. Menyimpan olahan dari data keuangan untuk keperluan manajemen
d. Menyajikan informasi keuangan yang lengkap, akurat, efektif dan efisien 
e. Memudahkan proses audit bagi Auditor dengan merubah tata cara audit manual menjadi Electronic Data Processing (EDP) audit

4. Manfaat yang diperoleh pemerintah daerah dengan adanya aplikasi SIMDA

a. Database terpadu, jadi tidak perlu input berulang-ulang data yang sama;

b. Data yang sama akan tercek dan re-cek secara otomatis (validasi data terjamin);

c. Fleksibel, dapat menghasilkan informasi sesuai dengan kebutuhan dimana:

1) Hasil dapat disesuaikan menurut perundang-undangan yang berlaku, dan

2) Hasil dapat disajikan berdasarkan kebutuhan manajemen pemerintah daerah untuk mengambil keputusan/ kebijakan

5. peraturan pemerintah daerah terkait SIMDA

Deputi pada Pengawasan Bidang Penyelenggaraan Keuangan Daerah, memandang penting dalam memfasilitasi Pemerintah Daerah dengan adanya program aplikasi SIMDA Keuangan yang digunakan sebagai pendorong pelaksanaan tata kelola keuangan Daerah sesuai dengan peraturan yang berlaku, efisien, efektif, transparan, akuntabel. Hal ini penting, karena berguna untuk meningkatkan kualitas Laporan Keuangan Pemerintah Daerah dan menuju terwujudnya tujuan Pemerintah Daerah yaitu good governance.

Penelitian terdahulu tentang Evaluasi Penerapan SIMDA Keuangan pada Dinas mendapatkan hasil yang beragam seperti penelitian yang dilakukan pada DPPKA Kepulauan Sangihe mendapatkan hasil positif setelah diterapkannya Sistem Informasi Manajemen Daerah Keuangan kemudian proses penyajian dalam laporan keuangan menjadi lebih cepat dan akurat (Darea, 2015). Hasil penelitian Harmadhani dan Yuli (2013) bahwa hasil analisis penerapan SIMDA Keuangan pada DisKes Kabupaten Nganjuk yaitu diketahui dengan menerapkan aplikasi SIMDA Keuangan ini dapat menunjukkan kenaikan rata rata dari biasanya, artinya 
informasi yang dihasilkan oleh program aplikasi SIMDA Keuangan menjadi lebih berkualitas dalam mempengaruhi pengambilan keputusan oleh manajemen. Menurut penelitian Trivena, Jantje dan Lidya (2015) hasil evaluasi penerapan SIMDA Keuangan di Daerah Maluku sangat membantu dalam pengelolaan keuangan daerah, namun masih ada beberapa kendala seperti harus membuat jurnal penyesuaian pada pengakuan untuk utang dan pengakuan piutang pada persediaan.

Menurut penelitian dari Edi dan Moh. Sabran (2020) penerapan program aplikasi SIMDA Keuangan pada Dinas Lingkungan Hidup Kabupaten Toli-toli dapat diketahui hasilnya sangat membantu dalam pengelolaan data informasi keuangan pada dinas tersebut sehingga menjadi lebih tepat dan akurat. Berbeda dengan hasil penelitian Suwandi (2016) pada Pemerintah Kabupaten Purworejo, aplikasi SIMDA Keuangan dapat melaksanakan pengelolaan keuangan daerah secara terintegrasi, fitur yang digunakan cukup sederhana, namun masih ditemukan beberapa kendala seperti konektivitas komputer kerja ke server pusat SIMDA dan adanya ada masalah di bug program sehingga program seringkali hang, selain itu register program pada badan pengelola keuangan pemerintah yang bertele-tele dan membutuhkan waktu yang lama.

\section{METODE PENELITIAN}

Penelitian ini merupakan jenis penelitian kuantitatif dengan menggunakan metode perhitungan arikunto (2010: 160). Metode penelitian ini adalah dengan cara observasi dan wawancara. Peneliti menggunakan instrumen pendukung dalam bentuk $e$-formulir wawancara. Kemudian responden menanggapi sejumlah pertanyaan yang telah peneliti susun yaitu berupa uji ketergunaan diterapkannya SIMDA Keuangan pada Dinas Kepemudaan Olahraga dan Pariwisata Kota magelang. Indicator dalam pengujian ketergunaan diantaranya yaitu kemudahan mempelajari, efisiensi, kemudahan diingat, tingkat kesalahan dan kepuasan 
responden. Tahapan-tahapan yang dilakukan penulis dalam penelitian ini yaitu dimulai dari menetapkan subjek/sistem yang akan di analisis, menentukan responden, membuat skrip observasi pengujian ketergunaan, menyusun pertanyaan-pertanyaan terkait wawancara, menganalisis data yang terkumpul, dan membuat kesimpulan.

Lokasi dalam penelitian kali ini adalah Dinas Kepemudaan Olahraga dan Pariwisata (DISPORAPAR) Kota Magelang yang merupakan satu dari beberapa Organisasi Perangkat Daerah (OPD) yang menerapkan SIMDA keuangan.

Penelitian kali ini evaluasi dan analisa data untuk hasil uji ketergunaan mengadopsi cara analisa data yang dilakukan oleh (Eko Saputra, dkk 2010). Penulis telah menyusun pertanyaan-pertanyaan yang di dalamnya terdapat beberapa pertanyaan yang harapan jawabannya ialah bernilai negatif (tidak), yaitu pada kategori tingkat kesalahan, yaitu apakah ada kesalahan yang terjadi dari dalam sistem, maka jawaban yang diharapkan adalah tidak ada kesalahan yang terjadi di dalam sistem. Kategori kepuasan penggunaan sistem, yaitu apakah menurut responden dibutuhkan perubahan pada aplikasi SIMDA keuangan, maka jawaban yang diharapkan adalah tidak dibutuhkannya perubahan pada sistem. Setelah memperoleh perhitungan presentase total keseluruhan jawaban, maka dapat diperoleh kesimpulan pengujian ketergunaan.

Namun, dalam penelitian ini, penulis menambahkan aturan dimana angka 1 (satu) atau tanda centang $(\sqrt{ })$ dapat diberikan pada jawaban "tidak bisa ditemukan" dan sebaliknya untuk angka $\mathbf{0}$ (Nol) atau tanda $\mathbf{x}$ (silang) diberikan pada jawaban "bisa ditemukan" dengan catatan bahwa jawaban yang diharapkan dari pertanyaan ialah jawaban yang bernilai negatif.

\section{HASIL DAN PEMBAHASAN}

Dinas Kepemudaan Olahraga dan pariwisata di Kota Magelang atau (DISPORAPAR) merupakan salah satu dari beberapa Organisasi Pemerintah 
Daerah yang ada di lingkup Pemerintahan Kota Magelang yang menaungi kegiatan Bidang Kepemudaan, Bidang Olahraga dan Bidang Kepariwisataan di Kota Magelang. DISPORAPAR merupakan salah satu dari beberapa Organisasi Perangkat Daerah (OPD) di Kota Magelang yang menerapkan program aplikasi yaitu SIMDA keuangan. SIMDA Keuangan merupakan program aplikasi yang ditujukan atau digunakan untuk membantu Pemerintah Daerah dalam pengelolaan keuangan daerahnya.

Menggunakan aplikasi ini, satuan kerja perangkat daerah dapat melaksanakan pengelolaan keuangan daerah secara terintegrasi dimulai dari penganggaran, penatausahaan, hingga akuntansi dan pelaporannya.

1. Penentuan Responden

Responden diambil sesuai dengan pengguna yang menggunakan aplikasi SIMDA Keuangan, dimana di kantor DISPORAPAR Kota Magelang terdapat 2 (dua) orang operator SIMDA Keuangan. Data penelitian ini diperoleh dari 2 operator SIMDA Keuangan DISPORAPAR Kota Magelang dengan cara menjawab pertanyaan yang ada di $e$-formulir dalam google form yang telah dibuat oleh penulis.

Tabel 1. Penentuan Responden

\begin{tabular}{lllll}
\hline Operator & Nama & Jabatan & Umur & Jenis Kelamin \\
\hline 1 & Sri Ardiastuti, S.E & Kasubag Keuangan & 40 & Perempuan \\
\hline 2 & Ari Wulandari & Tenaga Administrasi/Operator & 25 & Perempuan \\
\hline
\end{tabular}

2. Skenario pengujian ketergunaan

Skenario pengujian ketergunaan disini adalah naskah tugas pengujian ketergunaan yang akan ditanyakan kepada responden berdasarkan kemudahan dipelajari, efisiensi, kemudahan diingat, tingkat kesalahan, dan kepuasan.

a. Skenario untuk login : masuk ke aplikasi SIMDA melalui perangkat yang tersedia.

b. Skenario pemilihan menu pengolahan data : masuk ke halaman-halaman yang terdapat pada menu. 
c. Skenario penginputan data keuangan : lakukan proses input data keuangan yang biasa dilakukan.

d. Skenario penelusuran laporan keuangan : lakukan penelusuran salah satu laporan keuangan.

e. Skenario untuk logout : keluar dari aplikasi

\section{Menyusun Pertanyaan Uji Ketergunaan Untuk Wawancara}

Pada tahap ketiga, penulis menyusun pertanyaan uji ketergunaan dari aplikasi SIMDA Keuangan tersebut yang ditujukan oleh operator aplikasi SIMDA Keuangan pada DISPORAPAR Kota Magelang. Yang dalam hal ini akan diberikan pada saat sesi wawancara terhadap kedua responden tersebut. Pertanyaanpertanyaan yang diajukan merupakan pertanyaan yang telah dipersiapkan sesuai dengan kriteria ketergunaan yang mencakup ruang lingkup penerapan dan penggunaan aplikasi SIMDA Keuangan.

4. Menganalisis data yang terkumpul

Pada tahap ke-empat, yaitu menganalisis data yang sudah terkumpul. Untuk menganalisis data yang diperoleh maka, diperlukan sebuah teknik analisis data sehingga data yang telah diperoleh mempunyai makna atau nilai apabila dianalisis. Pada penelitian ini analisa data hasil uji ketergunaan mengadopsi cara analisa data yang dilakukan oleh (Eko Saputra, dkk: 2010). Namun dalam penelitian ini, penulis menambahkan beberapa aturan yaitu: dimana angka $\mathbf{1}$ (satu) atau tanda centang $(\sqrt{ })$ diberikan pada jawaban "tidak bisa ditemukan" dan sebaliknya dimana angka 0 (nol) atau tanda $\mathbf{x}$ (silang) diberikan pada jawaban "bisa ditemukan" dengan catatan apabila jawaban yang diharapkan dari pertanyaan ialah jawaban yang bernilai negatif.

Adapun perhitungan nilai yang digunakan dalam uji ketergunaan pada penelitian ini yaitu :

$$
\begin{aligned}
& \text { Nilai }=\text { Skor } / \text { Jumlah Responden }=100 / 2=50 \\
& \text { Total }=\text { jumlah nilai } / \text { jumlah pertanyaan }
\end{aligned}
$$


Total Keseluruhan=jumlah total/ 5

Setelah memperoleh perhitungan presentase total keseluruhan jawaban, maka dapat diperoleh kesimpulan pengujian usability sesuai dengan tabel kuantitatif untuk hasil perhitungan yang diperoleh dari kuesioner pada usability testing dengan ketentuan berikut ini:

Tabel 2. Kuantitatif Hasil Perhitungan Kuesioner Pengujian Ketergunaan

\begin{tabular}{lll}
\hline \multicolumn{1}{c}{ Persentase } & \multicolumn{1}{c}{ Kualifikasi } & \multicolumn{1}{c}{ Hasil } \\
\hline $85-100 \%$ & Sangat baik & Berhasil \\
\hline $65-84 \%$ & Baik & Berhasil \\
\hline $55-64 \%$ & Cukup & Tidak Berhasil \\
\hline $0-54 \%$ & Kurang & Tidak Berhasil \\
\hline
\end{tabular}

Berdasarkan hasil uji ketergunaan oleh kedua Responden, dapat dihitung presentase jawaban responden untuk mengetahui seberapa besar presentase ketergunaan yang dimiliki oleh SIMDA Keuangan Dinas Kepemudaan Olahraga dan Pariwisata Kota Magelang.

5. Hasil Tugas Skenario Pengujian Ketergunaan

Dari hasil skenario tugas pada uji ketergunaan oleh kedua responden, maka diperoleh hasil presentase tugas skenario sebagai berikut:

Tabel 3. Presentase Hasil Tugas Skenario

\begin{tabular}{llllll}
\hline No Responden & \multicolumn{5}{c}{ Task Skenario } \\
\cline { 2 - 6 } & $\mathbf{1}$ & $\mathbf{2}$ & $\mathbf{3}$ & $\mathbf{4}$ & $\mathbf{5}$ \\
\hline $\mathbf{1}$ & $\sqrt{ }$ & $\sqrt{ }$ & $\sqrt{ }$ & $\sqrt{ }$ & $\sqrt{ }$ \\
\hline $\mathbf{2}$ & $\mathrm{X}$ & $\sqrt{ }$ & $\mathrm{X}$ & $\sqrt{ }$ & $\sqrt{ }$ \\
\hline Hasil & $62,5 \%$ & $87,5 \%$ & $50 \%$ & $78,57 \%$ & $75 \%$ \\
\hline
\end{tabular}

Tabel 3 menunjukan bahwa task 1 mendapat nilai 62,5\%, dimana responden 1 berhasil menjalankan skenario sedangkan responden 2 belum berhasil. Task 2 mendapat nilai $87,5 \%$, dimana semua responden berhasil menjalankan skenario. Task 3 mendapat nilai sebesar 50\%, dimana ada responden yang tidak berhasil dalam menjalankan skenario, yaitu responden $1 \& 2$. Task 4 mendapat 
nilai 78,57\%, dimana semua responden berhasil menjalankan skenario. Task 5 mendapat nilai 75\%, dimana semua responden berhasil menjalankan skenario.

6. Hasil Wawancara Pengujian Ketergunaan

Berdasarkan hasil uji ketergunaan oleh responden 1 dan responden 2, dapat dihitung presentase jawaban responden untuk mengetahui seberapa besar presentase daya guna diterapkannya SIMDA Keuangan di Dinas Kepemudaan Olahraga dan Pariwisata Kota Magelang sebagai berikut:

Tabel 4. Hasil Wawancara Pengujian Ketergunaan.

\begin{tabular}{llll}
\hline No & Indikator & Responden 1 & Responden 2 \\
& & & \\
\hline 1. & Kemudahan Mempelajari & $62,5 \%$ & $37,5 \%$ \\
\hline 2. & Efisiensi & $87,5 \%$ & $12,5 \%$ \\
\hline 3. & Kemudahan Diingat & $50 \%$ & $50 \%$ \\
\hline $\mathbf{4 .}$ & Tingkat Kesalahan & $78,57 \%$ & $21,43 \%$ \\
\hline $\mathbf{5 .}$ & Kepuasan & $75 \%$ & $25 \%$ \\
\hline Total & & $78,57 \%$ & $21,43 \%$ \\
\hline Total Keseluruhan & $1,850 / 27=68,52 \%$ & \\
\hline
\end{tabular}

Melihat hasil di atas dapat diketahui bahwa Sistem Informasi Manajemen Daerah (SIMDA) Keuangan yang digunakan di Dinas Kepemudaan Olahraga dan Pariwisata Kota Magelang memiliki nilai baik, yaitu dengan presentase total $68,52 \%$. Berdasarkan kegiatan penelitian yang telah dilakukan dapat disimpulkan bahwa, dari kegiatan penugasan yang dilakukan terhadap 2 orang operator aplikasi SIMDA Keuangan yang menjadi responden pada penelitian ini diketahui bahwa secara umum seluruh tugas dapat dilaksanakan dengan baik oleh responden, secara umumnya dapat dilihat bahwa aplikasi SIMDA Keuangan di Dinas Kepemudaan Olahraga dan Pariwisata Kota Magelang dapat dijalankan dengan baik.

Selanjutnya, perhitungan persentase jawaban responden pada wawancara uji ketergunaan pada aplikasi SIMDA Keuangan pada Dinas Kepemudaan Olahraga dan Pariwisata Kota Magelang dari aspek ketergunaan, diketahui bahwa untuk aspek kemudahan dipelajari diperoleh angka sebesar 62,5\%, aspek efisiensi 
diperoleh angka sebesar 87,5\%, aspek kemudahan untuk diingat diperoleh angka 50\%, aspek untuk tingkat kesalahan diperoleh angka sebesar 78,57\%, dan aspek kepuasan dengan angka sebesar 75\%. Maka berdasarkan hasil evaluasi/pengujian pada aspek Kegunaan dapat disimpulkan bahwa Sistem Informasi Manajemen Daerah (SIMDA) Keuangan yang digunakan di Dinas Kepemudaan Olahraga dan Pariwisata Kota Magelang memiliki nilai baik, yaitu dengan presentase 68,51\%.

Berdasarkan evaluasi dan analisa yang penulis lakukan, diketahui bahwa masih ada beberapa hal yang tidak ditemukan di dalam aplikasi SIMDA Keuangan yang digunakan pada kantor Dinas Kepemudaan Olahraga dan Pariwisata Kota Magelang, salah satunya ialah tidak ditemukannya panduan yang terintegrasi di dalam aplikasi SIMDA Keuangan tersebut.

Dari hasil yang diperoleh, maka penulis memberikan beberapa rekomendasi agar diberikan penambahan fitur atau fasilitas panduan yang terintegrasi di dalam SIMDA Keuangan, sehingga akan memberikan kemudahan bagi pengguna aplikasi SIMDA Keuangan ini. Panduan yang dimaksud dapat berupa bentuk video tutorial yang diletakkan di satu menu tertentu di dalam Aplikasi SIMDA. Sedangkan desain rekomendasi untuk penambahan fitur panduan yang penulis usulkan adalah ditambahkan menu panduan pada SIMDA Keuangan setelah menu help, sehingga tampilannya menjadi seperti berikut ini :

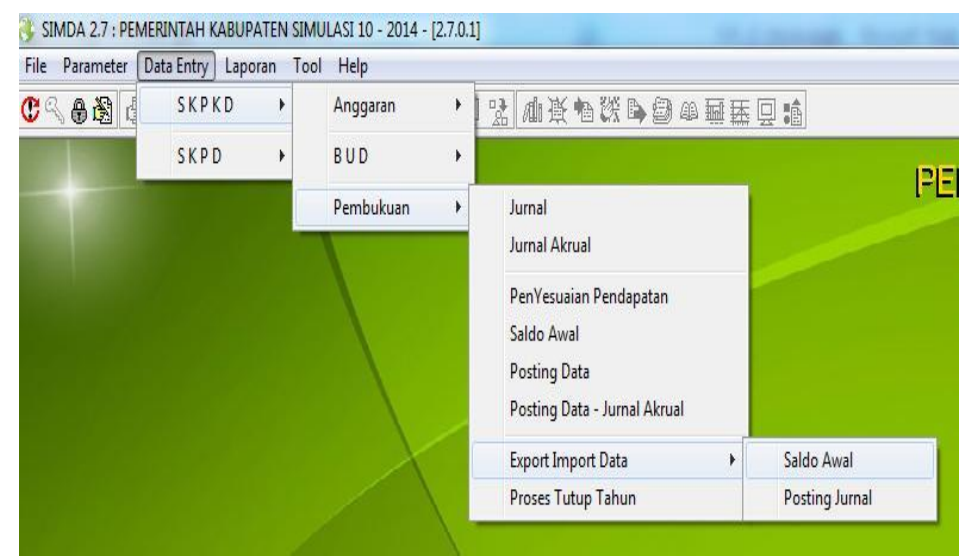

Gambar 1. Tampilan Halaman Usulan Penambahan Menu Panduan Sumber: SIMDA Keuangan versi 2.7 


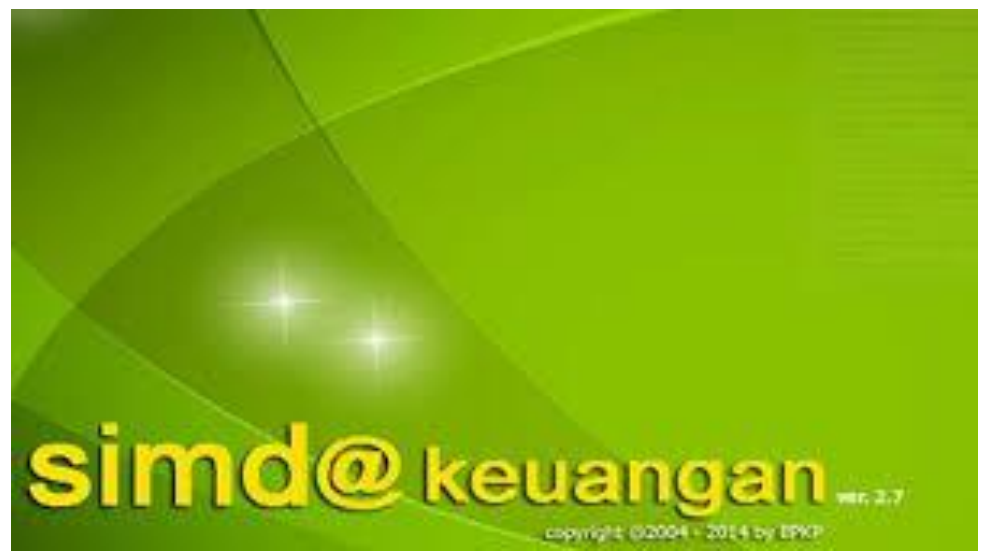

Gambar 2. Tampilan Halaman Panduan Aplikasi SIMDA Keuangan Sumber: SIMDA Keuangan versi 2.7

\section{KESIMPULAN}

Berdasarkan kegiatan penelitian yang telah dilakukan dapat disimpulkan bahwa, penelitian ini diketahui bahwa secara umum seluruh tugas dapat dilaksanakan dengan baik oleh responden, secara umumnya dapat dilihat bahwa aplikasi SIMDA Keuangan di Dinas Kepemudaan Olahraga dan Pariwisata Kota Magelang dapat dijalankan dengan baik.

Selanjutnya, perhitungan persentase jawaban responden pada wawancara uji ketergunaan pada aplikasi SIMDA Keuangan pada Dinas Kepemudaan Olahraga dan Pariwisata Kota Magelang dari aspek ketergunaan dapat disimpulkan bahwa Sistem Informasi Manajemen Daerah (SIMDA) Keuangan yang digunakan di Dinas Kepemudaan Olahraga dan Pariwisata Kota Magelang memiliki nilai baik, yaitu dengan presentase $68,51 \%$.

Saran dari penulis yaitu kemampuan sumber daya manusianya ditingkatkan kembali, dan untuk pegawai yang mengoperasionalkan SIMDA ini tidak hanya terbatas 2 orang. sehingga nantinya informasi yang dihasilkan lebih akurat dan efektif. Kemudian diperlukannya pedoman pengoperasionalan aplikasi SIMDA Keuangan bagi operator aplikasi SIMDA Keuangan. 


\section{DAFTAR RUJUKAN}

Arikunto. 2016. Prosedur Penelitian Suatu Pendekatan Praktik. Rineka Cipta. Budiman, F. dan A. F. I. 2013. Pendekatan Technology Acceptance Model dalam Kesuksesan Implementasi Sistem Informasi Manajemen Daerah. Jurnal WRA, 1 (1), 78 -

Darea. 2015. Evaluasi Penerapan Sistem Informasi Manajemen Daerah (Simda) Keuangan Pada Dppka Kabupaten Kepulauan Sangihe. Jurnal Riset Ekonomi, Manajemen, Bisnis Dan Akuntansi, vol 3 no 2.

Edi, M. S. 2020. Evaluasi Penerapan Sistem Informasi Manajemen Daerah (Simda) Keuangan Pada Dinas Lingkungan Hidup Kabupaten Tolitoli. Jurkami :Jurnal Pendidikan Ekonomi, Volume 5,.

Gaol, Chr, J. L. 2008. Sistem Informasi Manajemen Pemahaman dan Aplikasi. PT. Grasindo.

Harmadhani, Y. 2013. Analisis Penerapan Sistem Informasi Manajemen Keuangan Daerah (Simda Keuangan) Dalampengolahan Data Keuangan pada Organisasi Pemerintah Daerah (Studi Kasus pada Dinas Kesehatan Kabupaten Nganjuk). Jurnal Akuntansi Aktual, Vol. 2, No, hlm. 25-33.

Kumorotomo. 2004. Sistem Informasi Sektor Publik. BPFE UGM.

Machmud, R. 2013. Hubungan Sistem Informasi Manajemen dan Pelayanan dengan Kinerja Pegawai Pada Rutan Makassar. Jurnal Capacity STIE AMKOP Makassar, Vol. 9 No. ISSN : 1907-3313.

McLeod, R. J. 1997. Sistem Informasi Manajemen (Edisi Bahasa Indonesia). Prenhallindo.

Saputra E. Dkk. 2014. Usability Testing untuk Mengukur Penggunaan Website. Jurnal Teknik Informatika, 12.

Suwandi. 2016. Penerapan Dan Penilaian Sistem Informasi Manajemen Daerah (Simda) Di Kabupaten Purworejo Dalam Membantu Pengelolaan Akuntansi Pemerintahan. Jurnal Fokus Bisnis, Volume 15,.

Trivena, jantje, L. 2015. Analisis Penerapan Sistem Informasi Manajemen Daerah (Simda) Keuangan Pada Badan Keuangan Dan Aset Daerah Kabupaten Maluku Tenggara. Jurnal Riset Akuntansi Going Concern, 12(2), 201. 